\section{Новое окно возможностей для сибирских аграриев}

В августе 2016 г. в Забайкальске начато строительство железнодорожного терминала для экспорта российского зерна в Китай. Оператором проекта выступает ООО «Забайкальский зерновой терминал». Гендиректор компании Карен ОВСЕПЯН ответил на вопросы «ЭКО» В ходе XII «Зернового круглого стола» в Новосибирске.

Ключевые слова: экспорт зерна, Сибирский федеральный округ, Китай, зерновой терминал

«Мы уже около пяти лет занимаемся инициативой “Новый сухопутный зерновой коридор Россия - Китай”, - рассказал К. Овсепян. - Идея проекта родилась в 2011 г. в среде руководителей агропромышленных компаний, столкнувшихся с проблемой сбыта своей продукции. За пять лет мы собрали данные об экспортном потенциале Сибирского федерального округа, о перспективах зернового рынка Китая, рассмотрели несколько логистических моделей, приняли участие в деятельности группы по разработке “Стратегии развития зерновой отрасли до 2030 г.”, созданной в Минсельхозе России. При нашем содействии в стратегию включены такие необходимые для развития и господдержки отрасли целевые индикаторы, как развитие семеноводства, увеличение элеваторных мощностей, рост экспорта, а также создание новой для отрасли структуры сухопутных зерновых терминалов».

Ограниченность внутреннего спроса и удаленность от экспортных каналов сбыта являются основными факторами, сдерживающими развитие растениеводства в Сибири. Создание сухопутного зернового коридора в один из крупнейших в Азии рынков продовольствия - Китай - способно в корне переломить ситуацию, в разы увеличив экспортный потенциал сибирского агропромышленного комплекса.

«На данный момент все существующие коридоры зернового экспорта - морские, - рассказывает К. Овсепян. - Но, во-первых, транспортное плечо до морских портов из Сибири слишком большое, что значительно удорожает стоимость экспортных поставок, делая их экономически нерентабельными; во-вторых, при перевозке морем надо сначала довезти товар по железной дороге от элеватора отгрузки до портового элеватора, затем перегрузить на судно, потом морское плечо, снова перегрузка в элеватор в порту получателя, и уже оттуда зерно идет либо по железной дороге, либо автотранспортом до покупателя, при этом каждая перевалка стоит времени и денег. Сухопутный зерновой коридор, лишенный этих ограничений, в перспективе станет самым выгодным маршрутом для поставки в Китай сибирских зерновых, бобовых и масличных культур, которые смогут составить мощную конкуренцию американской и канадской продукции».

Общая стоимость проекта не раскрывается, но, по словам К. Овсепяна, сроки окупаемости «примерно вдвое меньше, чем у большинства сельхозпроектов, так что государственная поддержка не потребуется». Впрочем, когда речь идет о взаимоотношениях с таким непростым партнером, как Китай, административный ресурс может оказаться гораздо важнее прямого бюджетного софинансирования, а он у «Забайкальского зернового терминала» имеется. Проект заручился поддержкой властных структур различного уровня - от регионального правительства до Министерства сельского хозяйства РФ, свою заинтересованность подтвердили также руководство ОАО «РЖД» и крупнейший зернотрейдер Китая - компания COFCO. Меморандум о строительстве в Забайкальске зернового терминала подписал Президент РФ В.В. Путин в рамках визита в Китай в июне 2016 г. При этом сам терминал выступает исключительно как инфраструктурный объект. «Мы не торгуем, мы переваливаем. В качестве основных видов деятельности указаны только перевалка, оказание сопутствующих услуг», сказал гендиректор.

В начальный период после сдачи первой очереди мощность терминала составит около 800-900 тыс. т зерна, что не превышает 6\% валового сбора зерновых в СФО (13,5 млн т в 2015 г.), но в перспективе, по мнению К. Овсепяна, экспортный потенциал сибирских зернопроизводителей может быть увеличен в несколько раз. Запроектирована уже вторая очередь терминала, которая позволит увеличить мощность до 20 млн т в год, но решение о ее строительстве может быть принято только после выхода на проектную мощность первой очереди, достижение проектных показателей по ней планируется к 2025-2026 гг. 
На сегодня, по данным Росстата, площадь сельскохозяйственных угодий в Сибирском федеральном округе составляет около 47 млн га, из них под посевами зерновых и бобовых культур около 10 млн га, при средней урожайности 15-17 ц/га (варьируется по годам в зависимости от погодных условий). По мнению К. Овсепяна, «только за счет улучшения агрономической культуры и технологий сибирские аграрии могли бы поднять урожайность минимум вдвое», плюс есть еще резервы наращивания валового сбора за счет увеличения площади посевов.

«Если нам представится возможность наращивать экспорт зерна, это будет большой поддержкой для нашего региона»,отмечает председатель исполнительной дирекции ассоциации «Сибирское соглашение» А. Иванков, добавив, что конечно же, лучше продавать продукты глубокой переработки, однако пока ее нет, можно наращивать экспорт.

«Понятно, что если появится возможность продавать зерно на экспорт, все начнут заниматься этой деятельностью, и могут возникнуть проблемы у переработчиков, - комментирует К. Овсепян. - Поэтому, безусловно, им уже сейчас нужно самоорганизовываться, используя нормативные, законодательные механизмы для защиты своих интересов. Но не давать развиваться сельскому хозяйству огромного региона в интересах сотни игроков на рынке переработки - это тоже не очень справедливо... К тому же у наших китайских партнеров существует государственное определение технологического и экономического передела: зерно - у нас, массовое производство мяса и т. п. - у них. Причина в том, что один из приоритетных показателей в Китае - занятость населения, тогда как в России, наоборот, рабочих рук не хватает, а в мясном животноводстве людей на условную единицу продукции нужно больше, чем в современном растениеводстве».

«Для развития двусторонних российско-китайских отношений это - уникальный проект, - продолжает глава «Забайкальского зернового терминала». - В отличие от многих других инициатив здесь создается долгосрочная точка совместного роста в той логике взаимовыгодных партнерских отношений, которые Китай описывает в своей концепции Экономического пояса Великого Шелкового пути. Суть их в том, что от любого взаимодействия Китай ждет адекватной отдачи. В нашем случае одно из обязательных условий Китая - поставка в обмен на российское зерно китайской машинотехнической продукции для развития инфраструктуры зернового коридора. В частности, уже в среднесрочной перспективе потребуется строительство десятков современных элеваторов, в том числе узловых, необходимых для того, чтобы балансировать нагрузку на железную дорогу и осуществлять приемку, подработку, хранение и равномерную отгрузку в соответствии с требованиями покупателя. Кроме того, развитие экспортоориентированного производства будет способствовать увеличению доходов селян, а значит, и росту потребления, что простимулирует импорт товаров народного потребления из Китая, а это для китайской стороны тоже важно».

Долгосрочная потребность Китая в наращивании импорта зерновых, зернобобовых и масличных культур связана как с ростом населения этой страны, так и с изменением структуры потребления. «Это и третья волна урбанизации, и борьба с бедностью, - перечисляет К. Овсепян, - что означает массовый переход бывших сельских жителей из категории производителей в число потребителей продовольствия. Плюс есть еще целевая установка правительства Китая удвоить доходы населения к 2020 г., что вызовет изменения в рационе питания, в том числе - рост потребления мяса. Имеют значение также экологические проблемы и дефицит пресной воды: перед Китаем стоит задача к 2025 г. снизить ее отребление, притом что более $40 \%$ зерновых выращивается на орошаемых полях. Для сибирских аграриев все это открывает значимое окно возможностей».

«В Китае сейчас идут серьезные перемены в структуре потребления зерновых, - подтверждает генеральный директор ООО «Прозерно» В. Петриченко. - Страна будет снижать свои гигантские запасы пшеницы и кукурузы, сопоставимые с годовым потреблением Китая. И, судя по всему, соответственно будет меняться структура потребления... По визитам первых лиц, по тому, как идут согласования сертификационных протоколов ${ }^{1}$, мы видим, что экспорт зерна в Китай - вопрос не такого уж

117 декабря 2015 г. Россия и КНР подписали протоколы о фитосанитарных требованияхкпшенице, кукурузе, рису, соеи рапсу, экспортируемым из РФ. 
далекого будущего. Но это совершенно точно не станет прорывом ближайшего или следующего сезонов. Это будет поступательный, медленный, трудный поход на новую площадку».

«Организация долгосрочного сотрудничества - сложная задача, так как из соображений национальной безопасности сфера экспорта и импорта зерна находится на особом контроле и в России, и в Китае. Без координирующей роли государства нам не обойтись, - отмечает К. Овсепян. - Все эти особенности требуют долгосрочного межгосударственного диалога, определенной формализации, поскольку все тарифные, квотовые, фитосанитарные и прочие нюансы должны быть долгосрочными и прозрачными для обеих сторон: производство должно соответствовать спросу, а спрос должен быть прогнозируемым. Поэтому, по нашему мнению, наращивание сельхозпроизводства в Сибири должно происходить на программной основе - речь идет о долгосрочной стратегии на уровне федерального правительства.

Вероятно, здесь необходимо принятие долгосрочного межправительственного соглашения, аналогичного тому, которое существует по российским поставкам газа - чтобы видеть долгосрочную потребность, расписанную по годам. Но в целом сибирское зерно может быть конкурентоспособным на рынке».

Материал подготовила Э.Ш. Веселова, кор. «ЭКО» 